\title{
Acetic acid fermentation properties and antioxidant activity of lemongrass vinegar
}

\author{
Mi-Ran $\mathrm{Yi}^{1}$, Kang Chang-Hee ${ }^{1,2}$, Hee-Jung $\mathrm{Bu}^{*}$ \\ ${ }^{1}$ Biotechnology Regional Innovation Center, Jeju National University, Jeju 63243, Korea \\ ${ }^{2}$ Faculty of Chemistry and cosmetics, Jeju National University, Jeju 63243, Korea
}

\section{레몬그라스 식초의 초산발효 특성과 항산화 활성}

\author{
이미란 ${ }^{1} \cdot$ 강창희 $^{1,2}$ - 부희정 ${ }^{1 *}$ \\ ${ }^{1}$ 제주대학교 생명과학기술혁신센터, ${ }^{2}$ 제주대학교 화학·코스메틱스학부
}

\begin{abstract}
This study investigated acetic acid fermentation properties and antioxidant activity of vinegar by addition of lemon grass to develop high quality vinegar by using lemongreass. Traditional brown rice wine contained $5 \%$ lemongrass powder and had an alcohol content of $7.2 \%$. The wine was fermented by Acetobacter. sp. RIC-V and made into lemongrass vinegar $(\mathrm{LV})$. The $\mathrm{pH}$ and total acidity of the $\mathrm{LV}$ were $3.13 \%$ and $7.21 \%$, respectively. Fructose was detected whereas glucose, sucrose, and maltose were not detected. Among organic acids, acetic acid was highest at $3658.6 \mathrm{mg} \%$; trace amounts of lactic acid, citric acid, malic acid, tartaric acid, and oxalic aicd were detected. Of the 17 free amino acids, glutamic acid, histidine, alanine, and proline were mainly detected. To conduct total polyphenol content and ABTS radical scavenging activity, 3\% and 5\% lemongrass powder (P3LV, P5LV) and $1 \%, 2 \%$, and $3 \%$ of lemongrass extract (E1LV, E2LV, E3LV) were added to $L V$, respectively. Total phenolics increased as the added lemongrass powder and extract increased. Total phenolics were 490.9, 559.4, and 895.7 $\mu \mathrm{g}$ gallic acid equivalents $/ \mathrm{mL}$ in brown rice vinegar, LV, P5LV. ABTS radical scavenging activities were $43.2 \%$, $58.0 \%$, and $91.0 \%$ in brown rice vinegar, $L V, P 5 L V$, respectively. These results show that lemongrass vinegar has considerable potential as a high quality functional vinegar with antioxidative effects.
\end{abstract}

Key words : lemongrass, vinegar, acetic acid, fermentation, antioxidant

\section{서 론}

식초는 오랜 역사를 가진 발효식품중의 하나로 유기산, 당류, 아미노산 등을 함유하여 독특한 향과 맛을 가져 주로 조미료로서의 역할을 한다. 식초는 크게 그 제조법에 따라 발효주정을 초산발효하는 양조식초와 발효과정 없이 ethylene이나 acetylene으로부터 유기합성을 통해 만든 빙초 산을 원료로 물, 향신료 등을 더해 만든 합성식초로 구분된

*Corresponding author. E-mail : tang006@nate.com Phone : 82-64-485-2438 Fax : 82-64-726-3539

Received 7 August 2017; Revised 19 August 2017; Accepted 24 August 2017.

Copyright (c) The Korean Society of Food Preservation. All rights reserved.
다(1). 또한 양조식초에는 누룩을 이용하여 만든 발효주정 을 초산발효 하는 전통방식과 효모를 이용한 발효주정을 초산발효 하는 상업적인 방식이 있다(2). 이러한 제조방법 과 식초의 원료에 따라 식초의 유기산, 유리아미노산 등 휘발성 성분들이 다르고 전통방식의 초산발효 시 이러한 성분의 함량이 높은 것으로 보고되었으며, 이러한 성분들 은 체지방 감소 도움을 주고, 전분분해효소 저해, 신진대사 활성화를 통해 당뇨병과 같은 성인병 예방에 효능이 있음이 연구되었다(2-6). 그뿐만 아니라 식초에는 노화를 비롯한 각종 성인병의 원인이 되는 활성산소를 억제시키는 항산화 효능이 있다고 알려져 있다 $(5,7,8)$. 인체는 에너지를 만들어 내는 과정에서 산소를 사용하고 이러한 대사 과정에서 활성 산소종이 계속해서 생겨나게 된다. 정상적인 상태에서 신 체는 superoxide dismutase, peroxidase와 비타민 A, C, E 
등에 의한 효소성, 비효소서 반응에 의해 이러한 물질을 적절히 소거하고 몸의 균형을 이루며(9), 적절한 수준의 활성산소는 세포사이의 신호전달 등의 역할을 한다(10). 하지만 질병, 스트레스, 비정상적 대사작용 등에 의해 활성 산소가 과다하게 생성되고 적절한 소거가 이루어지지 않는 다면 활성산소는 세포막, 미토콘드리아, DNA등에 손상을 입히고 이러한 세포손상에 의해 염증, 암, 혈관질환 등이 발생하게 된다(11).

이와 같이 식초의 항산화 활성, 동맥경화, 고혈압, 콜레스 테롤 저해, 피로회복, 체지방 감소, 미백, 항주름 등의 건강 과 미용적인 측면에서의 다양한 효능이 알려지면서 조미료 로써의 역할뿐 아니라 음료, 기능성식품으로 활용되고 있 다 $(12,13)$. 식초의 다양한 생리활성이 연구되면서 제품의 고급화를 위해 전통방식의 자연발효 식초, 풍미를 더한 호 박식초, 파인애플 식초, 보리수열매 식초 등 여러 천연원료 와 그 효능을 이용한 식초들의 개발되고 있다(14).

허브(herb)는 라틴어 herba에서 유래되었지만 줄기 잎, 꽃, 뿌리 등의 부위가 식품으로 활용되며(15), 여러 가지 방향성분에 의해 음식의 향과 맛을 증진시키고 불쾌한 냄새 를 없애기 위한 향신료로 많이 활용된다. 또한, 다양한 기능 성 생리활성 물질을 함유하여 화장품, 건강보조제 같은 다 양한 분야에서 활용되고 있다(16). 레몬그라스(Cymbopogon citratus, lemon grass)는 이름과 같이 레몬향이 나는 허브의 일종으로 벼목 볏과의 여러해살이풀이다. 인도, 말레이시 아와 같은 열대지방에서 많이 재배되어왔으나, 최근에는 기후의 변화와 허브의 활용이 늘어나면서 우리나라에서도 재배되고 있다. 레몬그라스에 대한 연구는 추출물의 총 폴 리페놀 함량, 항산화활성, 추출 오일의 항균, 항곰팡이 활성 이 보고되었으며, 식품의 활용한 연구로는 레몬그라스 분 말을 첨가한 스펀지케이크와 머핀에 대한 연구가 있었다 (15-19). 허브류를 활용한 식초에 대한 연구는 레몬밤을 활 용한 식초개발에 대한 학위논문이 유일하고(20), 특히 아직 까지 레몬그라스를 활용한 식초에 대한 연구는 보고되지 않았다.

따라서 본 연구에서는 레몬그라스를 첨가하여 전통방식 의 발효주정을 만들고 선행연구(21)에서 분리한 우수분리 균주를 활용하여 초산발효한 고품질 식초개발을 위해 초산 발효 특성을 살피고, 유리당, 유기산, 유리아미노산 함량, 총 폴리페놀 함량과 항산화 활성을 분석하고자 한다.

\section{재료 및 방법}

\section{재료 및 시약}

레몬그라스는 2016년 제주도내 J업체에서 재배, 건조한 것을 분쇄하여 냉동 보관하면서 사용하였다. 유리당 분석 에 사용된 4개의 표준물질 fructose, glucose, sucrose, maltose, 유기산 분석에 사용된 6개의 표준물질 oxalic acid, tartaric acid, malic acid, lactic acid, acetic acid, citric acid, 총 폴리페놀 함량 분석에 사용된 Folin-Ciocalteau's phenol reagent, gallic acid와 ABTS라디칼 소거활성 분석에 사용된 2,2'-azinobis(3-ethylbenzothiazoline-6-sulfonic acid, ABTS) 는 모두 Sigma Chemical Co.(St. Louis, MO, USA)에서 구입 하였다.

\section{발효 주정}

고두밥은 현미를 세척한 후 정제수에 12 시간 침지시킨 후 증기로 1 시간 30 분 가열하였으며 30 분 뜸들인 후 $25^{\circ} \mathrm{C}$ 로 냉각하여 사용한다. 살균한 병에 고두밥 $1,000 \mathrm{~g}$, 누룩 200 $\mathrm{g}$ 을 가하여 잘 으깬 후 수곡 $100 \mathrm{~g}$, 양파 $10 \mathrm{~g}$, 제수 2,500 $\mathrm{L}$ 를 가하여 잘 혼합하고 매일 1 회 교반하며 $25^{\circ} \mathrm{C}$ 에서 7 일간 발효 하였다. 고두밥을 지을 때 여기에 고두밥대비 레몬그 라스 건조분말 $5 \%$ 를 첨가한 것을 레몬그라스발효주정, 첨 가하지 않은 것을 일반 발효주정으로 한다. 각각의 알코올 함량은 $7.2,8.6 \%$ 였다.

\section{초산발효 배지의 제조}

초산균 분리를 위한 평판 배지는 mannitol $2.5 \%$, yeast extract $0.5 \%$, peptone $0.3 \%$, agar $1.5 \%, \mathrm{CaCO}_{3} 1 \%$, ethanol $3 \%$ 의 비율로 하여 ethanol을 제외한 나머지를 고압멸균기 (DS-191A, Dasol Int Co., Ltd., Gwangju, Korea)에서 $121^{\circ} \mathrm{C}$, 15 분간 살균하여 $45^{\circ} \mathrm{C}$ 로 냉각한 다음 ethanol은 사용 직전 에 무균적으로 첨가하여 제조하였고, 초산균 종초 액체 배 지는 mannitol $2.5 \%$, yeast extract $0.5 \%$, peptone $0.3 \%$, ethanol $3 \%$ 의 비율로 제조하여 사용하였다.

\section{레몬그라스 식초제조}

초산발효에 사용한 균주로는 자체분리균주인 Acetobacter sp. RIC-V를 사용하였으며(21), 동결보관중인 균주를 액체 배지에 배양하여 활성화 한 후 칼슘카보네이트를 포함하는 평판배지에 배양하여 투명환 형성을 확인 후 산생성이 우수 한 콜로니를 사용하여 종초를 배양하였다. 초산발효는 발 효주정 $90 \%$ 에 종초 $10 \%$ 를 접종하여, $30^{\circ} \mathrm{C} 150 \mathrm{rpm}$ shaking incubator에서 4 주간 배양하였다. 레몬그라스발효주정, 일 반발효주정에 각각 종초를 접종하여 총산도의 변화를 측정 하며, 레몬그라스 식초를 제조하였다. 추가적으로, 레몬그 라스의 첨가방법에 따른 항산화 효능의 차이를 확인하고자 제조된 레몬그라스식초에 레몬그라스 건조 분말을 3,5\% 첨가하여 24시간 침지한 후 레몬그라스 분말 $3,5 \%$ 침지 식초(P3LV, P5LV)로 하고, 레몬그라스 잎을 열수추출, 농 축하여 $10{ }^{\circ} \mathrm{Brix}$ 가 되게 한 후 $1,2,3 \%$ 첨가하여 레몬그라스 농축액 $1,2,3 \%$ 첨가 식초 $(\mathrm{E} 1 \mathrm{LV}, \mathrm{E} 2 \mathrm{LV}, \mathrm{E} 3 \mathrm{LV})$ 로 하여 총 폴리페놀 함량과 $\mathrm{ABTS}$ 라디칼 소거활성을 비교하였다. 
유리당, 유기산 함량 분석

유리당과 유기산 함량은 시료를 $3,000 \mathrm{rpm}$ 에서 원심분리 시키고 상층액을 Sep-Pak Column 18 cartridge(Waters Associate Inc., Milford, MA, USA)를 통과시킨 후 $0.45 \mu \mathrm{m}$ membrane filter(Woongki Science Co., Ltd., Seoul, Korea)로 여과한 것을 HPLC(Waters 2695, Waters Associate Inc., Milford, MA, USA)로 분석하였다.

유리당 분석을 위한 HPLC 분석 칼럼은 Prevail ${ }^{\mathrm{TM}}$ Carbohydrate ES $(4.6 \times 250 \mathrm{~mm}, 5 \mu \mathrm{m}$, Grace, Deerfield, IL, $\mathrm{USA}$ ), 검출기는 $\mathrm{ELSD}$, 이동상으로는 $70 \%$ acetonitrile을 분 당 $0.8 \mathrm{~mL}$ 의 속도로 이동시켰다. 유리당 함량은 농도별로 제조한 표준물질인 fructose, glucose, sucrose 및 maltose를 분석하여 얻은 표준곡선으로부터 정량하였다.

유기산 분석을 위한 HPLC 조건은 Prevail ${ }^{\mathrm{TM}}$ organic $\operatorname{acid}(4.6 \times 150 \mathrm{~mm}, 3 \mu \mathrm{m}, \mathrm{Grace})$ 칼럼을 사용하여 PDA 210 $\mathrm{nm}$ 에서 검출하였으며, 이동상으로는 $\mathrm{pH} 2.5$ 로 조정된 25 $\mathrm{mM} \mathrm{KH} \mathrm{PO}_{4}$ 용액을 분당 $1 \mathrm{~mL}$ 의 속도로 이동시켰다. 분리 된 각 피크는 유기산 표준물질인 oxalic acid, tartaric acid, malic acid, lactic acid, acetic acid 및 citric acid의 표준곡선으 로부터 정량하였다.

\section{아미노산 함량 분석}

아미노산 분석을 위해 시료 $0.5-1 \mathrm{~g}$ 을 시험관에 취하여 $6 \mathrm{~N} \mathrm{HCl} 6 \mathrm{~mL}$ 을 넣고 질소가스로 충전시키면서 밀봉하여 $115^{\circ} \mathrm{C}$ 에서 24 시간 분해하였다. 분해된 시료를 $6 \mathrm{~N} \mathrm{NaOH}$ 로 중화시켜 증류수로 정용하였다. 시료를 여과한 후 $10 \mu \mathrm{L}$ 을 취하여 borate buffer $90 \mu \mathrm{L}$ 와 혼합시키고 AccQ 유도체 시약 을 $20 \mu \mathrm{L}$ 첨가 후 $55^{\circ} \mathrm{C}$ 에서 10 분간 반응하였다. AccQ$\mathrm{Taq}(3.9 \times 150 \mathrm{~mm}$, waters, Milford, MA, USA) 칼럼을 사용하 여 형광(EX: $250 \mathrm{~nm}, \mathrm{Em}: 395 \mathrm{~nm})$ detector에서 검출하였으 며, 이동상으로는 $10 \%$ AccQ Taq Eluat A, $60 \% \mathrm{ACN}$ 를 사용하여 $0.8 \mathrm{~mL} / \mathrm{min}$ 속도로 이동시켰다. 분리된 각 피크는 표준물질의 표준곡선으로부터 정량하였다.

\section{총 폴리페놀 함량 측정}

총 페놀 함량은 Folin-Denis 방법으로 측정하였다(22). 시료 $200 \mu \mathrm{L}$ 와 증류수 $1,800 \mu \mathrm{L}$ 를 혼합하고, Folin-Ciocalteau's phenol reagent $200 \mu \mathrm{L}$ 를 가하여 잘 섞은 후 5 분간 상온에서 반응시켰다. 이 용액에 $2 \mathrm{M} \mathrm{Na}_{2} \mathrm{CO}_{3} 400 \mu \mathrm{L}$ 를 넣어 혼합한 다음 증류수를 가하여 $4 \mathrm{~mL}$ 로 조정하였다. 이 용액을 실온 암소에서 1시간 동안 방치한 후, spectrophotometer(BioTek, USA)를 이용하여 $725 \mathrm{~nm}$ 에서 흡광도를 측정하였고, gallic acid를 이용한 검량선과 비교하여 $\mu \mathrm{g}$ gallic acid equivalents $(\mathrm{GAE}) / \mathrm{mL}$ 으로 총 페놀 함량을 나타내었다.

\section{ABTS 라디칼 소거활성 측정}

$\mathrm{ABTS}$ 라디칼 소거활성은 $\operatorname{Re}$ 등(23)의 방법을 변형하여
측정하였다. 시험 용액은 증류수에 $7 \mathrm{mM} \mathrm{ABTS}$ 와 2.45 $\mathrm{mM}$ potassium persulfate를 첨가하여 상온에서 16시간 배양 하여 $\mathrm{ABTS}$ 양이온을 생성시킨 후 $734 \mathrm{~nm}$ 에서 흡광도의 값이 0.7 이하가 되도록 희석하여 제조하였다. 그 다음 ABTS 용액 $100 \mu \mathrm{L}$ 에 시료 용액 $100 \mu \mathrm{L}$ 을 가한 후 6분 후에 흡광도를 측정하였다. 음성 대조군 $(2.45 \mathrm{mM}$ potassium persulfate buffer)의 흡광도와 비교하여 흡광도를 감소시키 는 정도를 \%로 나타내었으며, 양성대조군으로는 ascorbic acid를 사용하였다.

\section{통계분석}

본 실험에서 얻어진 결과는 통계분석용 소프트웨어 SPSS version 14.0(SPSS, Inc., Chicago, IL, USA)을 이용하 여 통계 분석하였다. Duncan의 다중범위 검정(Duncan's multiple range test)을 사용하였다. 유의 수준은 p-value $<0.05$ 로 하였다.

\section{결과 및 고찰}

\section{레몬그라스 식초 초산발효}

본 연구에서는 발효주정의 제조단계에서부터 레몬그라 스를 첨가하여 발효주정을 제조한 후 초산발효하고 레몬그 라스를 첨가하지 않은 현미발효주정을 초산발효하여 비교 군으로 하였다. 레몬그라스 첨가 발효주정과 무첨가 발효 주정은 알코올 함량은 각각 $7.2,8.6 \%$ 로 두 가지 모두 높은 산도의 식초를 제조하기에는 적절하였으며, 2 일간 냉장보 관하여 고형분을 가라앉힌 후 상층액을 초산발효에 사용하 였다.

발효 전 후의 $\mathrm{pH}$ 측정결과 발효 전 $\mathrm{pH}$ 3.62에서 발효 후 $\mathrm{pH}$ 3.13으로 감소하는 것으로 나타났다. 이러한 결과는 총산도가 증가함에 따라 $\mathrm{pH}$ 가 감소하는 경향을 보였다는 $\operatorname{Sim}$ 등(24)의 연구와 흑마늘 식초 제조 시 총산도는 1.28-1.54\%에서 5.57-6.77까지 증가하였고, $\mathrm{pH}$ 4.36-4.47이 던 것이 발효 25일 후 $\mathrm{pH}$ 3.85-3.97로 감소하였다는 Choi 등(25)의 연구와 유사한 경향을 보임을 확인하였다.

총산도는 레몬그라스식초와 레몬그라스 무첨가 식초가 각각 $1.43,1.31 \%$ 에서 $7.21,7.42 \%$ 로 높은 총산도를 보여 레몬그라스 함유에 따른 초산발효 저해는 없는 것으로 보였 다. Park(26)은 주정발효 후 종초의 접종 없이 식초를 제조 하는 자연발효를 통한 배식초, 배흑미식초, 배민트식초, 현 미식초발효 결과 총산도는 4.01-5.05\%로 식품공전에 따른 국내 식초의 규격인 $4.0-20 \%$ 에는 충족하였으나, 낮은 총산 도를 보였다. 이와 달리 본 연구에서는 초산생성이 우수하 고 높은 알코올 함량에도 생육이 가능한 균주의 분리 및 그 균주를 이용한 종초를 초기에 접종함으로써 적정 초기산 도를 맞춰 유해균의 생장을 억제하고 $7 \%$ 이상의 식초 제조 
가 가능했던 것으로 사료된다.

본 연구에서 레몬그라스 식초의 발효기간이 4 주로 자연 발효 정치배양이 2-3개월 소요되는데 비해서는 짧았지만 일반적인 진탕배양에 비해 길어졌다. 같은 균을 사용한 선 행연구(21)에서 미숙과 식초 발효에서 초기 알코올 함량을 $5 \%$ 로 하였을 때 최고산도에 도달하기까지 발효기간이 10-13일 이었다. 그러나 본 연구에서의 초산발효의 경우 $7 \%$ 이상의 높은 알코올 농도에서 초산발효하여 최종 총산 도가 $7.21 \%$ 로 높은 산도의 식초 제조는 가능하였지만 발효 기간은 길어졌다는 것을 알 수 있었다. 이러한 발효기간의 결과는 발효 초기 알코올 함량이 비교적 높았으며, 그에 따른 최종 총산도가 높아 그에 도달하기까지 기간이 길어진 것으로 판단된다. Kang 등(27)과 Hong 등(28)은 유자식초, 복분자식초 제조 시 적정 초기 알코올 농도를 $5,6 \%$ 로 보았 으며, 각각에서 10,9 일 발효기간이 소요되어 본 연구에서 보다 짧은 발효기간을 보였다고 보고하였으며, $\mathrm{Ko}$ 와 $\mathrm{Ryu}(29)$ 는 사과식초 발효 시 에탄올 함량이 $6 \%$ 이하 일 때는 정상적으로 초산균의 생육하였지만 $8 \%$ 일 때는 acetic acid 초산균의 생육이 정상적으로 이루어지지 않았다고 하였다. Sung 등(30) 사과식초 발효연구에 따르면 알코올 함량이 $6,7 \%$ 일 때는 총산도 $7 \%$ 에 도달하기까지 3 일 소요되었으 며, 알코올 함량 $8 \%$ 인 경우 4일, $9 \%$ 인 경우 5일 소요되었다. 따라서 이와 같이 선행 연구들에서 일반적으로 알코올 함량 이 높을 때 최고 산도에 도달까지 발효기간이 길어진다는 연구 보고들로 알코올 함량은 초산균의 활성과 발효기간에 영향을 주는 것을 알 수 있었다.

Table 1. $\mathrm{pH}$, total acidity of lemongrass vinegar

\begin{tabular}{cccc}
\hline & Sample $^{1)}$ & Before fermentation & After fermentation \\
\hline \multirow{2}{*}{$\mathrm{pH}$} & $\mathrm{LV}$ & $3.62 \pm 0.00^{2)}$ & $3.13 \pm 0.05$ \\
& $\mathrm{~V}$ & $3.68 \pm 0.01$ & $3.04 \pm 0.02$ \\
\hline \multirow{2}{*}{ Total } & $\mathrm{LV}$ & $1.43 \pm 0.01$ & $7.21 \pm 0.04$ \\
acidity (\%) & $\mathrm{V}$ & $1.31 \pm 0.07$ & $7.42 \pm 0.11$ \\
\hline
\end{tabular}

${ }^{1)} \mathrm{LV}$, lemongrass vinegar maded from brown rice wine containing lemongrass; $\mathrm{V}$, general vinegar maded from brown rice wine.

${ }^{2)}$ Values are expressed as mean $\pm \mathrm{SD}$ of triplicate measurements.

\section{유리당}

레몬그라스 식초의 유리당 함량 분석 결과는 table 2 와 같이 fructose가 $0.81 \mathrm{~g} / 100 \mathrm{~g}$ 으로 가장 많았고, glucose, sucrose, maltose는 검출되지 않았다. Joo 등(2)은 전통방식 의 현미 발효식초 제조결과 glucese 함량이 높게 나왔는데, 이는 누룩을 활용한 발효주정에 초산균을 접종하여 발효하 였기 때문에 초산발효 중 누룩이 계속해서 전분질을 분해하 여 유리당 함량이 증가한 것으로 보고하였다. 하지만 본 연구에서는 발효주정 제조 후 2 일간 냉장보관 하여 고형분 을 최대한 가라앉힌 후 맑은액에 초산균을 접종하여 초산발
효 중 누룩균과 전분질이 최소화되었기 때문에 다른 경향을 보인 것으로 판단되었다. 또한 Shin 등(31)에 따르면 초산발 효 시 시간이 지남에 따라 유리당이 소비되어 줄어드는 경향을 보이고 이 때 sucrose가 가장먼저 소비되고 glucose 가 fructose보다 우선적으로 소비되었다고 하였는데, 본 연 구 결과도 발효기간이 길어짐에 따라 glucose, sucrose는 초산발효과정 중에 소비되고 fructose만 소량 남은 것으로 판단된다.

Table 2. Contents of free sugars $(\mathrm{g} / 100 \mathrm{~g})$ in lemongrass vinegar

\begin{tabular}{cccccc}
\hline Free sugars & Fructose & Glucose & Sucrose & Maltose & Total \\
\hline $\mathrm{LV}^{1)}$ & $0.81 \pm 0.00^{2)}$ & $\mathrm{ND}^{3)}$ & $\mathrm{ND}$ & $\mathrm{ND}$ & $0.81 \pm 0.00$ \\
\hline
\end{tabular}

${ }^{1)} \mathrm{LV}$, lemongrass vinegar maded from brown rice wine containing lemongrass.

${ }^{2)}$ Values are expressed as mean $\pm S D$ of triplicate measurements.

${ }^{3)} \mathrm{ND}$, not detected.

유기산

레몬그라스 식초의 유기산 분석결과는 table 3 과 같다. acetic acid가 3,658.58 mg\%로 가장 높았으며, 그다음으로 citric acid, lactic acid가 각각 $214.66,159.44 \mathrm{mg} \%$ 로 나타났 고, malic aicd, tartaric acid, oxalic acid 또한 소량 함유한 것으로 분석되었다. Joo 등(2)의 누룩을 이용한 발효 현미식 초 유기산 분석 연구에서 누룩을 이용한 전통 발효와 효모 를 이용한 상업발효로 현미식초의 유기산을 분석한 결과, 누룩을 이용한 발효주정으로 만든 식초의 경우 acetic aicd 가 2,507.0, 3,741.4 $\mathrm{mg} \%$ 로 가장 높았으면 다음으로 lactic acid, malic acid, tartaric acid, citric acid, oxalic acid함량이 소량 분석 되었으며, 효모를 이용한 상업 발효에서는 유사 한 결과이나 malic acid, tartaric acid는 trace만 되는 수준이 라고 하여 본 연구와 비슷한 경향임을 확인하였다. malic acid, tartaric acid은 사과, 포도에 많이 함유된 유기산이며, 소량이나 식초의 산미에 영향을 주는 중요한 성분으로(2), 본 연구에서도 누룩을 이용하여 이러한 유기산들이 다양하 게 검출되어 산미가 풍부한 제품 개발이 가능할 것으로 기대된다.

\section{유리아미노산 함량}

현미와 레몬그라스에 누룩을 가하여 발효한 발효주정을 초산발효한 레몬그라스 식초의 유리아미노산 함량을 분석 한 결과 table 4와 같다. Glutamic acid가 $232.64 \mathrm{mg} \%$ 으로 가장 높은 함량을 보였고, 다음으로 histidine, alanine, proline, aspartic acid, leucine이 각각 129.08, 112.31, 102.87, $68.85,62.56 \mathrm{mg} \%$ 으로 나타났다. Lee 등(32)은 누룩첨가량 과 배양방법을 달리한 현미식초의 유리아미노산 분석결과 누룩첨가량이 많을수록 유리아미노산 함량이 유의적으로 높았으며, 정치배양에서 주요 유리아미노산은 alanine, valine, luecine이였고, 진탕배양에서 주요 유리아미노산은 
alanine, glutamic acid, leucine, valine, proline으로 본 연구와 유사한 결과를 보였다. Joo 등(2)은 누룩을 이용한 전통 발효 방식과 효모를 이용한 상업적발효로 알코올 발효액을 초산발효하여 유리아미노산을 비교한 결과 누룩을 이용한 전통 발효 현미식초가 2.0-4.6배 높다고 하였으며, 누룩을 이용한 현미식초의 주요아미노산으로 glutamic acid, glycine, arginine, alanine, proline, tyrosine, valine, leucine으 로 나타나 본 연구결과와 유사하였다.

\section{총 폴리페놀 함량 및 $\mathrm{ABTS}$ 라디칼 소거활성}

피토케미칼이란 식물에 들어있는 다양한 화합물로 일반 적으로 영양소로 작용하지 않지만 광범위한 생리활성을 나타내는 물질들로, 그 종류가 매우 다양하고 폴리페놀류 도 이에 해당된다. 페놀이란 벤젠고리중 하나가 수산기로 치환된 화합물로 이러한 수산기가 2개 이상인 것을 폴리페 놀이라 하며 플라보노이드는 폴리페놀류의 큰 부류이다.
폴리페놀 화합물은 수산기를 통해 수소공여와 페놀고리구 조의 공명안정화, 금속이온과의 킬레이트 형성으로 자유라 디칼 형성을 막거나 지방과산화를 막는 등의 항산화 활성을 나타낸다(33-35). 레몬그라스는 isoscoparin, swertiajaponin, chlorogenic acid, and caffeic acid 등의 다양한 폴리페놀을 함유하고 있는 것으로 보고되었다(34).

레몬그라스 식초와 레몬그라스 분말 첨가량, 레몬그라스 농축액 첨가량에 따른 레몬그라스 식초의 총 폴리페놀 함량 과 ABTS 라디칼 소거활성을 분석하였다. 분석결과는 table 5 와 같다. 레몬그라스 무첨가 발효주정을 이용한 식초의 총 폴리페놀 함량은 $490.9 \mu \mathrm{g}$ gallic acid equivalents $(\mathrm{GAE}) / \mathrm{mL}$ 이며, $\mathrm{ABTS}$ 라디칼 소거활성은 식초 $2.5 \%$ 농도 에서 $43.2 \%$ 로 분석되었으며, 레몬그라스 식초의 경우 총 폴리페놀 함량이 $568.6 \mathrm{\mu g} \mathrm{GAE} / \mathrm{mL}, \mathrm{ABTS}$ 라디칼 소거활성 이 $58.0 \%$ 로 일반 발효주정 식초에 비해 유의적으로 높게 나타났다. 레몬그라스 건조 분말을 $3,5 \%$ 침지한 경우 총폴

Table 3. Contents of organic acids ( $\mathrm{mg} \%)$ in lemongrass vinegar

\begin{tabular}{cccccccc}
\hline Organic acids & Oxalic acid & Tartaric acid & Malic acid & Lactic acid & Acetic acid & Citric acid & Total \\
\hline $\mathrm{LV}^{1)}$ & $8.96 \pm 0.19^{2)}$ & $43.34 \pm 5.92$ & $50.87 \pm 15.04$ & $159.44 \pm 15.48$ & $3658.58 \pm 30.29$ & $214.66 \pm 111.13$ & $4,135.85 \pm 44.21$ \\
\hline
\end{tabular}

${ }^{1)} \mathrm{LV}$, lemongrass vinegar maded from brown rice wine containing lemongrass.

${ }^{2)}$ Values are expressed as mean $\pm \mathrm{SD}$ of triplicate measurements.

Table 4. Contents of free amino acids (mg\%) in lemongrass vinegar

\begin{tabular}{cc}
\hline Free amino acid & $\mathrm{LV}^{1)}$ \\
\hline Aspartic acid & $69.85 \pm 3.76^{2)}$ \\
Serine & $56.96 \pm 2.27$ \\
Glutamic acid & $232.64 \pm 9.08$ \\
Glycine & $16.81 \pm 2.63$ \\
Histidine & $129.08 \pm 4.94$ \\
Arginine & $15.20 \pm 0.26$ \\
Threonine & $52.69 \pm 2.61$ \\
Alanine & $112.31 \pm 2.58$ \\
Proline & $102.87 \pm 3.66$ \\
Cystine & $23.92 \pm 0.44$ \\
Tryosine & $20.71 \pm 1.34$ \\
Valine & $55.79 \pm 1.65$ \\
Methionine & $1.29 \pm 0.06$ \\
Lysine & $44.65 \pm 3.38$ \\
IsoLeucine & $34.64 \pm 1.84$ \\
Leucine & $62.56 \pm 1.73$ \\
Phenylalanin & $59.34 \pm 4.02$ \\
Total & $1,090.30 \pm 2.82$ \\
\hline
\end{tabular}

${ }^{1)} \mathrm{LV}$, lemongrass vinegar maded from brown rice wine containing lemongrass.

${ }^{2)}$ Values are expressed as mean \pm SD of triplicate measurements.
Table 5. Total polyphenol content and effects on ABTS radical scavenging activity of lemongrass vinegar added with lemongrass extract or powder

\begin{tabular}{ccc}
\hline Sample $^{1)}$ & $\begin{array}{c}\text { ug gallic acid equivalents } \\
(\mathrm{GAE}) / \mathrm{mL}\end{array}$ & $\begin{array}{c}\text { ABTS radical scavenging } \\
\text { activity (\%) at } 2.5 \%\end{array}$ \\
\hline $\mathrm{V}$ & $490.9 \pm 5.1^{2 \mathrm{a} 3)}$ & $43.2 \pm 0.7^{\mathrm{a}}$ \\
\hline LV & $559.4 \pm 3.4^{\mathrm{b}}$ & $58.0 \pm 0.5^{\mathrm{ab}}$ \\
\hline P3LV & $825.5 \pm 4.0^{\mathrm{f}}$ & $81.6 \pm 0.4^{\mathrm{d}}$ \\
P5LV & $895.7 \pm 4.2^{\mathrm{g}}$ & $91.0 \pm 1.4^{\mathrm{e}}$ \\
\hline E1LV & $594.7 \pm 22.7^{\mathrm{c}}$ & $54.0 \pm 1.5^{\mathrm{ab}}$ \\
E2LV & $619.9 \pm 1.2^{\mathrm{d}}$ & $62.4 \pm 2.3^{\mathrm{bc}}$ \\
E3LV & $783.3 \pm 18.4^{\mathrm{e}}$ & $68.8 \pm 0.7^{\mathrm{c}}$ \\
\hline
\end{tabular}

${ }^{1)} \mathrm{V}$, general vinegar maded from brown rice wine; $\mathrm{LV}$, lemongrass vinegar maded from brown rice wine containing lemongrass; P3LV, lemongrass vinegar added with lemongrass powder $3 \%$; P5LV, lemongrass vinegar added with lemongrass powder $5 \%$; EILV, lemongrass vinegar added with lemongrass extract 1\%; E2LV, lemongrass vinegar added with lemongrass extract $2 \%$; E3LV, lemongrass vinegar added with lemongrass extract $3 \%$.

${ }^{2)}$ Values are expressed as mean $\pm \mathrm{SD}$ of triplicate measurements.

${ }^{3)}$ Values with different letters $(a-e)$ in the column are significantly different at $p<0.05$ according to Duncan's multiple range test.

리페놀 함량이 각각 $825.5,895.7 \mu \mathrm{g} \mathrm{GAE} / \mathrm{mL}, \mathrm{ABTS}$ 라디 칼 소거활성이 각각 $81.6,91.0 \%$ 로 첨가량에 따라 유의적으 로 증가하는 것으로 나타났다. 레몬그라스 열수추출 농축 액을 $1,2,3 \%$ 첨가한 경우 총 폴리페놀 함량이 각각 594.7 , $619.9,783.3 \mu \mathrm{g} \mathrm{GAE} / \mathrm{mL}, \mathrm{ABTS}$ 라디칼 소거활성이 각각 
$54.0,62.4,68.8 \%$ 로 총 폴리페놀 함량의 경우 첨가량에 따라 유의적으로 증가하는 경향을 나타냈으나, ABTS 라디칼 소거활성의 경우 $3 \%$ 첨가군 만이 유의적인 차이를 나타냈 다. 이러한 결과는 Jeong 등(12)이 폴리페놀의 일종인 quercetin함량이 높은 것으로 알려진 양파식초를 발효제조 하여 총 폴리페놀 함량을 분석한 결과 $33.3 \mathrm{mg} / 100 \mathrm{~g}(333$ $\mu \mathrm{g} / \mathrm{g}$ )로 보고한 것보다 우수한 것으로 판단된다. $\mathrm{Ju}$ 등(16) 과 Lee 등(19)은 머핀, 스펀지케이크 제조 시 레몬그라스 분말 첨가에 따라 유의적으로 라디칼 소거활성이 높아졌다 고 하였다. 또한 Cheel 등(34)에 따르면 레몬그라스는 자유 유리기 소거활성이 있으며, 이는 레몬그라스에 함유된 폴 리페놀의 일종인 플라보노이드류 함량과 상관관계를 보인 다고 보고하여, 본 연구에서 레몬그라스 분말 첨가량, 추출 액 첨가량이 높아질수록 총 폴리페놀 함량이 높아지고 $\mathrm{ABTS}$ 자유유리기 소거활성이 높이진 것과 유사한 경향이 었다. Yi 등(21)에 따르면 폴리페놀 함량이 높을 것으로 알려진 미숙감귤과 감귤과즙을 $35 \%$ 첨가하여 식초를 제조 하여 경우 총 폴리페놀 함량이 각각 $1,546.6,230.9 \mu \mathrm{g}$ $\mathrm{GAE} / \mathrm{mL}$ 로 레몬그라스 식초가 미숙감귤식초 보다는 낮고 감귤 식초 보다는 높았다 $\mathrm{ABTS}$ 라디칼 소거활성은 미숙감 귤식초, 감귤식초 $2 \%$ 농도에서 각각 $62.0,17.9 \%$ 로 레몬그 라스 식초가 감귤식초보다는 우수하고 미숙과 식초보다는 약간 낮은 것으로 나타났으나 다. 레몬그라스 식초 제조 시 레몬그라스 함량이 고두밥대비 $5 \%$ 로 소량이었던 점을 고려할 때 우수한 것으로 사료된다. 따라서 전통적인 방법 으로 제조하여 다양한 유기산이 풍부한 레몬그라스 식초에 레몬그라스 분말 혹은 추출물을 추가적으로 첨가하여 상품 을 제조하였을 때 항산화 기능이 우수한 기능성 식초로 활용 가능할 것으로 사료된다.

\section{요 약}

본 연구는 제주도에서 재배된 레몬그라스를 활용한 식초 의 초산발효 특성과 품질특성 그리고 항산활 활성을 알아보 았다. 레몬그라스를 고두밥대비 $5 \%$ 첨가한 현미주정을 제 조한 결과 알코올 함량이 $7.2 \%$ 였다. 여기에 초산균인 Acetobacter sp. RIC-V 종초를 $10 \%$ 가하여 초산발효하여 레몬그라스 식초를 제조하였다. 초산발효 결과 $\mathrm{pH}$ 가 3.62 에서 3.13 으로 낮아졌으며, 총산도는 $1.43 \%$ 에서 $7.21 \%$ 로 증가하였다. 레몬그라스 식초의 유리당 분석결과 fructose 가 $0.81 \mathrm{~g} / 100 \mathrm{~g}$ 으로 나타났고, glucose, sucrose, maltose는 검출되지 않았다. 유기산 분석결과는 acetic acid가 $3,658.58$ $\mathrm{mg} \%$ 로 가장 높았으며, citric acid, lactic acid가 각각 214.66 $\mathrm{mg} \%, 159.44 \mathrm{mg} \%$ 로 나타났고, malic aicd, tartaric acid, oxalic acid 모두 소량 함유한 것으로 분석되었다. 유리아미 노산 분석결과 glutamic acid가 $0.233 \mathrm{~g} / 100 \mathrm{~g}$ 으로 가장 높은
함량을 보였고, histidine, alanine, proline, aspartic acid이 각각 $0.129 \mathrm{~g} / 100 \mathrm{~g}, 0.113 \mathrm{~g} / 100 \mathrm{~g}, 0.103 \mathrm{~g} / 100 \mathrm{~g}, 0.069$ $\mathrm{g} / 100 \mathrm{~g}$ 으로 나타났다. 총 폴리페놀 함량 분석 결과는 레몬 그라스 식초와 레몬그라스 무첨가 식초가 각각 $568.6 \mu \mathrm{g}$ $\mathrm{GAE} / \mathrm{mL}, 490.9 \mu \mathrm{g} \mathrm{GAE} / \mathrm{mL}$ 이며, 레몬그라스 식초에 레몬 그라스 분말과 추출물의 첨가량이 높을수록 높아져 레몬그 라스 분말 $5 \%$ 첨가군이 $895.7 \mu \mathrm{g} \mathrm{GAE} / \mathrm{mL}$ 로 가장 높았다. $\mathrm{ABTS}$ 라디칼 소거활성은 레몬그라스 식초와 레몬그라스 무첨가 식초 $2.5 \%$ 농도에서 각각 $58.043 .2 \%$ 로 분석되었으 며, 이 또한 레몬그라스 분말과 추출물의 첨가량이 높을수 록 높아져 레몬그라스 분말 $5 \%$ 첨가군이 $91.0 \%$ 로 가장 높은 저해율을 보였다. 결과 레몬그라스 식초는 총산도 7.21로 높고, 유기산, 아미노산 함량이 우수하며, 항산화 활성이 우수한 것으로 나타나 고품질의 기능성 식초로 활용 가능할 것으로 사료된다.

\section{감사의 글}

본 연구는 산업통상자원부와 한국산업기술진흥원의 지 역특화산업육성사업으로 수행된 연구결과입니다.

\section{References}

1. Mo HW, Jung YH, Jeong JS, Choi KH, Choi SW, Park CS, Choi MA, Kim ML, Kim MS (2013) Quality characteristics of vinegar fermented using omija (Schizandra chinensis Baillon). J Korean Soc Food Sci Nutr, 42, 441-449

2. Joo KH, Cho MH, Park KJ, Jeong SW, Lim JH (2009) Effects of fermentation method and brown rice content on quality characteristics of brown rice vinegar. Korean J Food Preserv, 16, 33-39

3. Ko YJ, Jeong DY, Lee JO, Park MH, Kim EJ, Kim JW, Kim YS, Ryu CH (2007) The establishment of optimum fermentation conditions for Prunus mume vinegar and its quality evaluation. J Korean Soc Food Sci Nutr, 36, 361-365

4. Jang SY, Sin KA, Jeong YJ (2010) Quality characteristics of apple vinegar by agitated and static cultures. J Korean Soc Food Sci Nutr, 39, 308-312

5. Jo DJ, Park EJ, Yeo SH, Jeong YJ, Kwon JH (2013) Physicochemical and antioxidant properties of commercial vinegars with high acidity. J Korean Soc Food Sci Nutr, 42, 1204-1210

6. Hong KP (2015) Inhibitory effects of fatty acids, 
polyphenols and organic acids on the glucoamylase activity. MS Thesis, Korea University, Korea, p 1-38

7. Xu Q, Tao W, Ao Z (2007) Antioxidant activity of vinegar melanoidins. Food Chem, 102, 841 - 849

8. Budak NH, Aykin E, Seydim AC, Greene AK, Guzel-Seydim ZB (2014) Functional properties of vinegar. J Food Sci, 79, 757-764

9. Krotz F, Sohn HY, Pohl U (2004) Reactive oxygen species : players in the platelet game. Arterioscler Thromb Vasc Biol, 24, 1988-1996

10. Morrell CN (2017) Reactive oxygen species : finding the right balance. Circ Res, 103, 571-572

11. Yi MR, Kang $\mathrm{CH}, \mathrm{Bu} \mathrm{HJ}$ (2017) Antioxidant and anti-inflammatory activity of extracts from kohlrabi (Brassica Oleracea var. Gonglodes). J Korean Oil Chemists' Soc, 34, 189-202

12. Jeong EJ, Park HJ, Cha YJ (2016) Fermented production of onion vinegar and its biological activities. Korean $\mathrm{J}$ Food Nutr, 29, 962-970

13. Hwang JY, Cho HY, Pyo YH (2016) Effect of unpolished rice vinegar containing monascus-fermented soybean on inhibitory activities of tyrosinase and elastase. J Korean Soc Food Sci Nutr, 45, 149-154

14. Cho KM, Hwang CE, Joo OS (2017) Change of physicochemical properties, phytochemical contents and biological activities during the vinegar fermentation of Elaeagnus multiflora fruit. Korean J Food Preserv, 24, 125-133

15. Chae IG, Kim HJ, Yu MH, Kim HI, Lee IS (2010) Antioxidant and antibacterial activity of commercially available herbs in korean markets. J Korean Soc Food Sci Nutr, 39, 141-1417

16. Ju T, Oh HS, Kim MJ, Kang ST (2016) Quality characteristics of sponge cake with lemon grass powder. Korean J Food Sci Technol, 48, 347-353

17. Velluti A, Sanchis V, Ramos AJ, Egido J, Marin S (2003) Inhibitory effect of cinnamon, clove, lemongrass, oregano and palmarose essential oils on growth and fumonisin B1 production by Fusarium proliferatum in maize grain. Int J Food Microbiol, 89, 145-154

18. Tzortzakis NG, Economakis CD (2007) Antifungal activity of lemongrass (Cympopogon citratus L.) essential oil against key postharvest pathogens. Innovative Food Sci Emerging Technol, 8, 253-258

19. Lee JW, Kim GJ, Rho KA, Chung KH, Yoon JA, An JH (2015) Quality characteristics and antioxidant activity of muffins containing lemongrass powder. Korean J Food
Nutr, 28, 794-801

20. Choi SK (2013) Quality characteristics and antioxidative activity of herb vinegar prepared with puffed rice and lemon balm. MS Thesis, Chonbuk National University, Korea, p 1-91

21. Yi MR, Hwang JH, Oh YS, Oh HJ, Lim SB (2014) Quality characteristics and antioxidant activity of immature Citrus unshiu vinegar. J Korean Soc Food Sci Nutr, 43, 250-257

22. Zhang Q, Zhang J, Shen J, Silva A, Dennis DA, Barrow CJ (2006) A simple 96-well microplate method for estimation of total polyphenol content in seaweeds. J Appl Phycol, 18, 445-450

23. Re R, Pellegrini N, Proteggente A, Pannala A, Yang M, Rice-Evans C (1999) Antioxidant activity applying an improved ABTS radical cation decolorization assay. Free Radic Biol Med, 26, 1231-1237

24. Sim HJ, Seo WT, Choi MH, Kim GW, Shin JH, Kang MJ (2016) Quality characteristics of vinegar added with different levels of black garlic. Korean J Food Cook Sci, 32, $16-26$

25. Choi MH, Sim HJ, Kim GH, Kang MJ, Seo WT, Shin JH (2016) The Quality characteristics of vinegar prepared with different forms of black garlic. J Agric Life Sci, 50, 179-190

26. Park YO (2016) Quality characteristics of fermented vinnegars using pear. Korean J Food Preserv, 23, 778-787

27. Kang SG, Jang MJ, Kim YD (2006) Isolation and culture conditions of Acetobacter sp. for the prodution of citron (Citrus junos) vinegar. Korean J Food Preserv, 13, 357-362

28. Hong SM, Kang MJ, Lee JH, Jeong JH, Kwon SH, Seo KI (2012) Production of vinegar using Rubus coreanus and its antioxidant activities. Korean J Food Preserv, 19, 594-603

29. Ko YJ, Ryu CH (2016) Optimum fermentation condition of apple vinegar added with korean rice wine lees extracts. J Agric Life Sci, 50, 193-200

30. Sung NH, Woo SM, Kwon JH, Yeo SH, Jeong YJ (2014) Quality characteristics of high acidty apple vinegar manufactured using two stage fermentation. J Korean Soc Food Sci Nutr, 43, 877-883

31. Shin JS, Lee OS, Jeong YJ (2002) Changes in the components of onion vinegars by two stages fermentation. Korean J Food Sci Technol, 34, 1079-1084

32. Lee SW, Kwon JH, Yoon SR, Woo SM, Yeo SH, Jeong YJ (2011) Quality characteristics of brown rice vinegar 
prepared using varying amounts of Nuruk (anamylolytic enzyme preparation) and employing different fermentation conditions. Korean J Food Preserv, 18, 26-32

33. Seerama NP, Adams LS, Henning SM, Niu Y, Zhang Y, Nair MG, Hebera D (2005) In vitro antiproliferative, apoptotic and antioxidant activities of punicalagin, ellagic acid and a total pomegranate tannin extract are enhanced in combination with other polyphenols as found in pomegranate juice. J Nutr Biochem, 16, 360-367
34. Cheel J, TheodulozC, Rodriguez J, Schmeda-Hirschmann G (2005) Free radical scavengers and antioxidants from lemongrass (Cnmbopogon citratus (DC.) Stapf.). J Agric Food Chen, 53, 2511-2517

35. Rice-Evans CA, Miller NJ, Paganga G (1997) Antioxidant properties of phenolic compounds. Trends Plant Sci, 2, 639-738 